\title{
IMPACT OF ORGANIC AND INORGANIC NITROGEN FERTILIZERS ON WASHINGTON NAVEL ORANGE TREES. I. VEGETATIVE GROWTH, YIELD AND SOIL PROPERTIES
}

\author{
H. A. Ennab(1), M. A. El Shemy (2) and M. H. Abd El Aziz(2) \\ Citrus Research Department ${ }^{(1)}$ and Handling Research Department ${ }^{(2)}$ \\ Horticulture Research Institute, Agriculture Research Center, Giza, Egypt
}

Received: Jul. 22, 2019 Accepted: Aug. 25, 2019

\begin{abstract}
Poultry manure has a salutary effect on soil fertility, increase plant nutrients and improving the soil conditions for citrus growth, productivity and ensure economic yield with a good quality. Therefore, a field experiment was conducted during 2017 and 2018 seasons on 20 year old Washington navel orange trees grown in a private orchard in Kafr El Sheikh Governorate, Egypt. This study aims to evaluating the effect of poultry manure and ammonium sulphate alone or in combination on soil chemical properties, vegetative growth and yield of Washington navel orange trees. The treatments consist of $T_{1}$ (100\% inorganic nitrogen), $T_{2}(66.6 \%$ inorganic nitrogen $+33.3 \%$ organic nitrogen), $T_{3}$ (50\% inorganic nitrogen $+50 \%$ organic nitrogen), $T_{4}$ (33.3\% inorganic nitrogen $+66.6 \%$ organic nitrogen) and $T_{5}$ (100\% organic nitrogen). Results indicated that, combined application of organic and inorganic nitrogen fertilizer especially $T_{4}$ (203.8 $\mathrm{kg} / \mathrm{feddan}$ ammonium sulphate +3.64 ton/feddan poultry manure) and $T_{3}$ (305.8 $\mathrm{kg} / \mathrm{feddan}$ ammonium sulphate +2.73 ton/feddan poultry manure) resulted in significant increase in $\mathrm{NH}_{4}^{+} \mathrm{N}, \mathrm{NO}_{3}{ }^{-} \mathrm{N}$, organic matter and $\mathrm{Zn}$; and decreased $\mathrm{pH}$, cadmium, lead and electrical conductivity of soil. Moreover, the treatments increased leaf content values of $\mathrm{N}, \mathrm{P}, \mathrm{K}, \mathrm{Ca}, \mathrm{Fe}, \mathrm{Mn}$ and $\mathrm{Zn}$ in both seasons. Data also indicated that application of $305.8 \mathrm{~kg} / \mathrm{feddan}$ ammonium sulphate +2.73 ton/feddan poultry manure $\left(T_{3}\right)$ and application of $203.8 \mathrm{~kg} / \mathrm{feddan}$ ammonium sulphate +3.64 ton/feddan poultry manure $\left(T_{4}\right)$ gave the highest values of tree size and vegetative growth in terms of shoot number/branch, shoot length, leaves number per shoot and leaf area of Washington navel orange trees compared to mineral nitrogen fertilizers only. As for yield and fruit quality, treatment of $T_{3}$ (50\% inorganic nitrogen $+50 \%$ organic nitrogen), $T_{4}$ (33.3\% inorganic nitrogen $+66.6 \%$ organic nitrogen) produced the highest yield and improve fruit quality in terms of fruit weight, fruit size and fruit firmness. This treatment also increased SSC\%, SSC/acid ratio and vitamin C and reduced acidity, nitrate and nitrite in fruit juice. In general, combined application of $305.8 \mathrm{~kg} / \mathrm{feddan}$ ammonium sulphate + 2.73 ton/feddan poultry manure $\left(T_{3}\right)$ was recommended for improving soil chemical properties and the best growth, yield, fruit quality and nutritional status of Washington navel orange trees.
\end{abstract}

Key words: Citrus sinensis, poultry manure, ammonium sulphate, fruit yield, leaf area.

\section{INTRODUCTION}

Nitrogen is one of the most important mineral nutrients for Washington navel orange tree growth and development. Nitrogen is essential in the synthesis of enzymes, vitamins, chlorophyll molecules, and is involved in nucleic and amino acid synthesis and protein production as well as interferes with the uptake of cations and anions (Fernandes and Rossiello 1995). So, nitrogen has an important role prerequisite for obtaining high yields and good quality produce from Washington navel orange. Chemical fertilizers are commonly used as source of nitrogen because they can ensure 
quick availability for trees. However, continuous application of inorganic nitrogen fertilizers not only increases the cost to out of reach for small farmers but also causes' soil deteriorates and pollution of the environment. Pollution problem resulted from leaching inorganic nitrogenous compounds such $\mathrm{NH}_{4}{ }^{+}, \mathrm{NH}_{3}$, $\mathrm{NO}_{2}^{-}, \mathrm{HNO}_{2}, \mathrm{NO}_{3}{ }^{-}$in to ground and surface waters, which has toxicological implications for animals and humans (Camargo and Alonso, 2006 and Wong et al., 2015). The organic manure applications supports farmers through reducing the cost of production and reduce the adverse effects of synthetic fertilizers on human health and the environment (lbe et al., 2011 and Bakshi et al., 2018). In this respect, poultry manure is a good alternative to reducing the use of chemical nitrogen fertilizers, which increase soil nitrogen storage, mineralization, improving soil, water, and air quality (Nahm, 2003 and Amanullah et al., 2007). Moreover, using poultry manure as a source of nitrogen have numerous benefits as a source of macro and micronutrients, increasing soil organic matter, improves soil structure and increases the water-holding capacity in sandy soils and improves drainage in clay soils. On other words, poultry manure has a great importance for sustainable production and improve the soil physical, chemical and biological properties (Canali et al., 2004; Sainju et al., 2010 and Kobierski et al., 2017). Previous studies emphasized the beneficial of poultry manure alone or combined with mineral fertilizer in citrus orchards for avoiding pollution and promoting growth, yield and fruit quality (Ferguson 1994; Rapisarda et al., 2010; lbe et al., 2011 and Cerda et al., 2012).

Therefore, the objective of this study was to evaluating the beneficial effects of poultry manure as a source of organic nitrogen and inorganic nitrogen alone or together on some soil properties, growth, and yield as well as fruit quality of Washington navel orange trees.

\section{MATERIALS AND METHODS}

This experiment was conducted during 2017 and 2018 seasons in a private orchard at Kafr EI Sheikh Governorate, Egypt, on 20 years old Washington navel orange trees (Citrus sinensis L.) budded on sour orange (Citrus aurantium L.) rootstock, planted at spacing of $5 \times 5$ meter apart in clay soil under surface irrigation system. Soil samples at $0-30$ and $30-60 \mathrm{~cm}$ depth before treatments and samples from poultry manure used in this study were taken for physical and chemical analysis according to Page et al., (1982), the data have been shown in Table (2). Forty five trees uniform in growth, vigour and productivity were selected, and arranged in a randomized complete block design, each treatment replicated three times with three trees per replicate. The experiment involved five treatments as shown in Table (1).

Table (1): Treatment details of nitrogen fertilization sources, calculated as basic of 126 units /feddan/year or $750 \mathrm{~g} \mathrm{~N} /$ tree/year

\begin{tabular}{|c|c|c|c|}
\hline $\begin{array}{c}\text { Treatment } \\
\text { number }\end{array}$ & Treatment details & $\begin{array}{c}\text { Ammonium } \\
\text { sulphate } 20.6 \% \mathrm{~N} \\
\mathrm{~kg} / \mathrm{feddan}\end{array}$ & $\begin{array}{l}\text { Poultry manure } 2.3 \\
\% \mathrm{~N} \text { ton/feddan }\end{array}$ \\
\hline$T_{1}$ & $100 \%$ inorganic & $611.6 \quad(3.64 \mathrm{~kg} /$ tree $)$ & 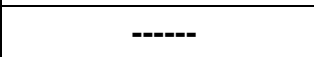 \\
\hline$T_{2}$ & $66.6 \%$ inorganic $+33.3 \%$ organic & 407.7 (2.42 kg/tree) & $1.82(10.8 \mathrm{~kg} /$ tree $)$ \\
\hline $\mathbf{T}_{3}$ & $50 \%$ inorganic $+\mathbf{5 0} \%$ organic & $305.8 \quad(1.82 \mathrm{~kg} /$ tree $)$ & 2.73 (16.2 kg/tree) \\
\hline$T_{4}$ & $33.3 \%$ inorganic $+66.6 \%$ organic & $203.8 \quad(1.21 \mathrm{~kg} /$ tree $)$ & 3.64 (21.6 kg/tree) \\
\hline$T_{5}$ & $100 \%$ organic & ----- & $5.46(32.5 \mathrm{~kg} /$ tree $)$ \\
\hline
\end{tabular}


Table (2): Analysis of poultry manure, and some physical and chemical characters of the experimental soil

\begin{tabular}{|c|c|c|c|c|}
\hline \multicolumn{3}{|c|}{ Soil analysis } & \multicolumn{2}{|c|}{ Poultry manure analysis } \\
\hline \multirow{2}{*}{ parameters } & \multicolumn{2}{|c|}{ Soil depth cm } & \multirow{2}{*}{ Parameters } & \multirow{2}{*}{ Values } \\
\hline & $0-30$ & $30-60$ & & \\
\hline Sand \% & 6.84 & 6.84 & Weight of $\mathrm{m}^{3} \mathrm{~kg}$ & 495.32 \\
\hline Silt \% & 33.87 & 30.74 & Moisture \% & 18.45 \\
\hline Clay \% & 59.29 & 62.42 & Organic matter \% & 35.42 \\
\hline Texture & Clayey & Clayey & Organic carbon \% & 26.33 \\
\hline pH 1:2.5 & 8.18 & 8.20 & pH 1:10 & 6.73 \\
\hline$E C \mathrm{dSm}^{-1} 1: 5$ & 1.20 & 0.98 & $E C \mathrm{dSm}^{-1} 1: 5$ & 0.89 \\
\hline Organic matter $\%$ & 1.30 & 0.98 & $\mathrm{C} / \mathrm{N}$ ratio & 11.44 \\
\hline $\mathrm{K}^{+} \mathrm{meq} / \mathrm{l}$ & 0.50 & 0.43 & $\mathrm{~N} \%$ & 2.30 \\
\hline $\mathrm{Ca}^{++} \mathrm{meq} / \mathrm{l}$ & 4.70 & 4.53 & $\mathbf{P} \%$ & 0.91 \\
\hline $\mathrm{Mg}^{++} \mathrm{meq} / \mathrm{l}$ & 3.77 & 3.35 & K \% & 1.36 \\
\hline $\mathrm{Na}^{+} \mathrm{meq} / \mathrm{l}$ & 12.87 & 11.48 & $\mathrm{Ca} \%$ & 0.180 \\
\hline $\mathrm{HCO}_{3}^{-} \mathrm{meq} / \mathrm{l}$ & 4.40 & 4.31 & $\mathrm{Mg} \%$ & 0.180 \\
\hline $\mathrm{Cl}^{-} \mathrm{meq} / \mathrm{l}$ & 6.69 & 6.23 & Fe ppm & 241.75 \\
\hline $\mathrm{SO}_{4^{--}} \mathrm{meq} / \mathrm{l}$ & 10.75 & 9.25 & Mn ppm & 127.17 \\
\hline $\mathrm{CO}_{3}^{--}$ & 0.00 & 0.00 & Zn ppm & 152.76 \\
\hline Total N, \% & 0.155 & 0.112 & -- & -- \\
\hline Available $P, \mathrm{mg} / \mathrm{kg}$ soil & 15.25 & 7.90 & -- & -- \\
\hline Available $\mathrm{K}, \mathrm{mg} / \mathrm{kg}$ soil & 1155 & 800 & -- & -- \\
\hline
\end{tabular}

Ammonium sulphate $\{(20.6 \% \mathrm{~N})$, mineral $\mathbf{N}\}$ was divided into three equal doses that added at the first week of March, June and August. Also, $200 \mathrm{~kg}$ calcium super phosphate $\left\{\left(15.5 \% \mathrm{P}_{2} \mathrm{O}_{5}\right)\right.$, mineral P\} was added once in December and $190 \mathrm{~kg}$ potassium sulphate $\left\{\left(48 \% \mathrm{~K}_{2} \mathrm{O}\right)\right.$, mineral $\left.\mathrm{K}\right\}$ was applied at two equal doses on March and late June. Potassium sulphate and Calcium super phosphate were applied to all treatments as a source of $K$ and $P$ in both seasons. The poultry manure was obtained from Poultry Department, Sakha Animal Production Research station, Kafr EI Sheikh, Egypt; it was broadcasted and incorporated into the root zone of tree in winter service at late December in both seasons.

\section{The following data was recorded:}

\section{Soil properties:}

At the end of the experiment, soil samples were collected from each treatment, dried and sieved through 2 $\mathrm{mm}$ for analysis of $\mathrm{pH}$, organic matter\%, $\mathrm{EC}, \mathrm{Cd}, \mathrm{Pb}$ and $\mathrm{Zn}$. The $\mathrm{pH}$ of soil samples was measured in 1:2.5 soils: distilled water suspension with the help of $\mathrm{pH}$ meter and organic matter was measured by chromic acid digestion method (Wilde et al., 1985). Electrical conductivity (EC), $\mathrm{NH}_{4}{ }^{+} \quad-\mathrm{N}, \mathrm{NO}_{3}{ }^{-} \quad-\mathrm{N}$ Cadmium (Cd), lead (Pd), and Zinc ( $\mathrm{Zn}$ ) were analyzed according to (Page et al., 1982).

\section{Leaf nutrient contents:}

Leaf samples were collected from each replicate, cleaned, washed and oven dried at $70^{\circ} \mathrm{C}$ to a constant weight, then ground and digested according to Evenhuis and DeWaard (1980) by using $\mathrm{H}_{2} \mathrm{SO}_{4}$ and $\mathrm{H}_{2} \mathrm{O}_{2}$ to determine the elements $\mathrm{N}, \mathrm{P}, \mathrm{K}, \mathrm{Ca}$ and $\mathrm{Mg}$. Total nitrogen $\%$ was determined by using the micro-kjeldahl method as described by 
Pregl (1945), Phosphorus \% was determined coloremetrically as described by Murphy and Riley (1962), Potassium \% was estimated by using flame photometer as described by Brown and Lillelland (1974), Ca, Mg, Fe, Mn and Zn were assayed with Atomic Absorption spectrophotometer (Unican SP 1900) according to Chapman and Pratt (1961).

\section{Tree size and vegetative growth:}

Percent of increase in tree height and canopy volume were calculated according to the following equation:

Percent of increase in variable $=\left[\left(X_{1}-\right.\right.$

$$
\left.\left.\mathrm{X}_{0}\right) / \mathrm{X}_{0}\right] \times 100
$$

Where, $X_{1}$ : Final tree height or canopy volume at December; $X_{0}$ : Initial tree height or canopy volume at January. Whereas, canopy volume was calculated according to the following equation: Canopy volume $=0.528 \times \mathrm{H} \times \mathrm{D}^{2}$. Whereas, $H=$ tree height, $D=$ tree diameter, the formula given by Castle (1983). Shoot number/branch, shoot length $(\mathrm{cm})$, leaves number/shoot and leaf area was measured in both seasons.

\section{Final fruit set and preharvest fruit drop \%:}

Final fruit set \% was calculated by using the following equation:

Final fruit set $\%=$ No. of fruits at end of June $\div$ total number of flower $\times 100$

Preharvest fruit drop \% was calculated as the equation:

Preharvest drop $\%=$ No. of mature fruits $\div$ total number of setted fruits $\times 100$.

\section{Fruit yield:}

Yield was harvested at December $18^{\text {th }}$ and $24^{\text {th }}$ in 2017 and 2018, respectively. Yield of each replicate was determined as number and weight $(\mathrm{kg})$ of fruits/tree.

\section{Fruit quality:}

Fruit quality was determining as follow: fruit weight $(\mathrm{g})$, fruit size $\left(\mathrm{cm}^{3}\right)$, fruit firmness was measured by fruit pressure tester on the two opposite sides of the fruits, and the average of the fruit firmness was calculated as $\left(\mathrm{kg} / \mathrm{cm}^{2}\right)$ and fruit juice content $\%$ was calculated as follow \{weight of extracted juice $\div$ fruit weight $\} \times 100$. Juice quality was determined as soluble solids content (SSC \%), total acidity and vitamin C. Nitrate $\left(\mathrm{NO}_{3}\right)$ and nitrite $\left(\mathrm{NO}_{2}\right)$ content (ppm/100 ml juice) in fruit juice were determined according to (A.O.A.C., 1990).

Statistical analysis was done as analysis of variance according to Snedecor and Cochran (1990), and the differences among treatment means were compared with Duncan multiple range tests at $5 \%$ level according Duncan (1955).

\section{RESULTS AND DISCUSSION}

\section{Soil properties:}

Data presented in Figure (1) show the effect of organic nitrogen fertilizer rates combined with doses of mineral nitrogen on chemical properties of clay soil after harvest yield of Washington navel orange trees. The results in Figure (1A) showed that, all treatments had significant effect on organic matter status of soil; organic matter percentage in the soil was gradually increased by increasing quantity applied of poultry manure per feddan. Application of $100 \%$ organic nitrogen $\left(T_{5}\right)$ gave the highest organic matter percentage followed by 33.3 inorganic nitrogen +66.6 organic nitrogen $\left(T_{4}\right)$, whereas treatment of $T_{1}$ (100\% inorganic nitrogen) recorded the lowest value of organic matter percentage in soil. These observations were corroborated with the findings of Ferguson (1994) and Kobierski et al., (2017) they concluded that, application of poultry manure for long term resulted in a significant increase in soil content of organic matter and organic carbon. 


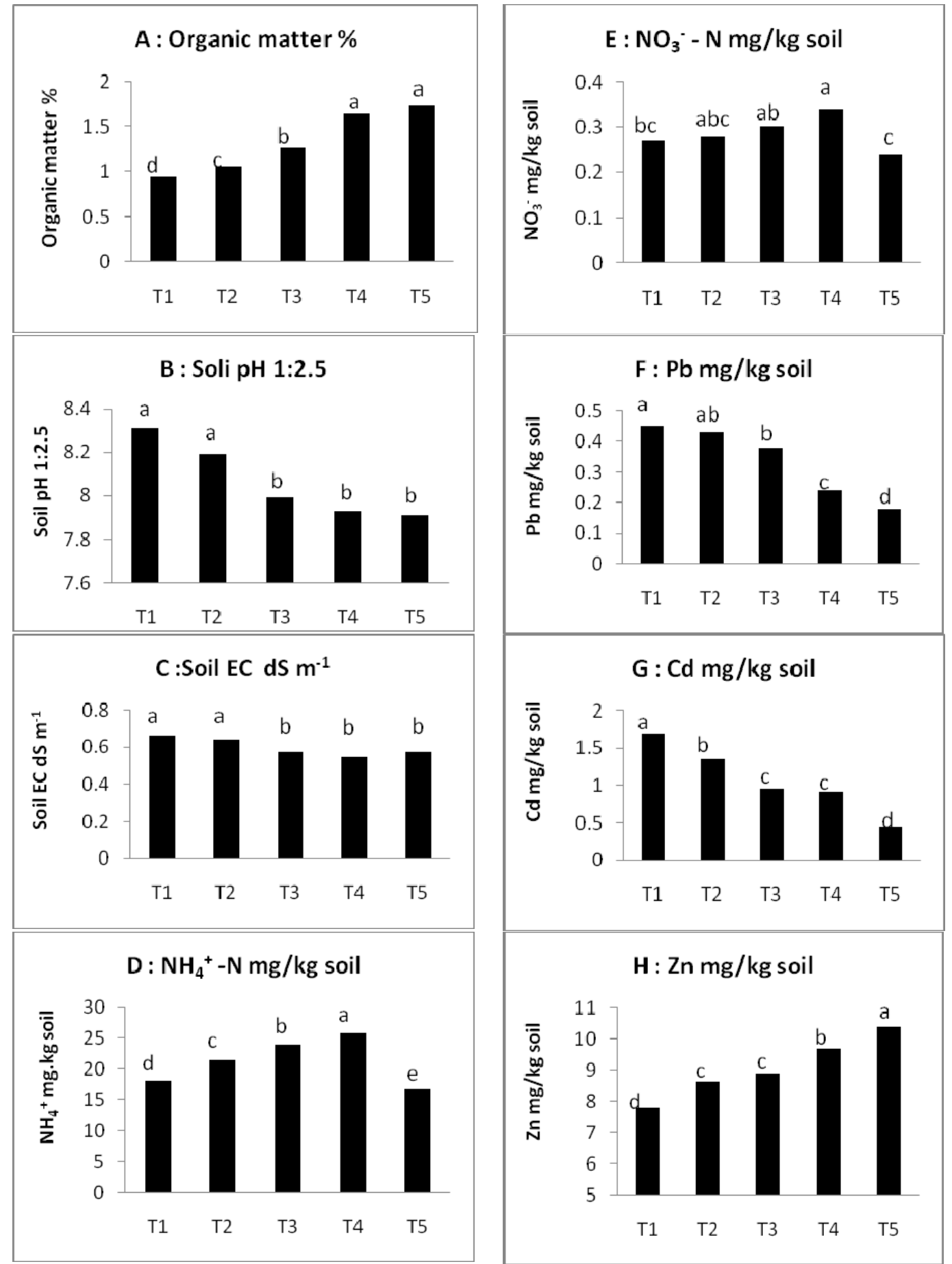

Figure (1). Effect of organic and inorganic nitrogen fertilizers on organic matter \% (A), pH (B), EC (C), NH4+-N (D), NO3- -N (E), Pb (F), Cd (G) and Zn (H) at the end of experiment of Washington navel orange trees.

( $\mathrm{T}_{1}: \mathbf{1 0 0 \%}$ inorganic; $\mathrm{T}_{2}: \mathbf{6 6 . 6 \%}$ inorganic $+33.6 \%$ organic; $\mathrm{T}_{3}: \mathbf{5 0 \%}$ inorganic $+\mathbf{5 0 \%}$ organic; $\mathrm{T}_{4}: 33.3 \%$ inorganic $+66.6 \%$ organic; $\mathrm{T}_{5}: 100 \%$ organic) 
Combined application of organic nitrogen and mineral nitrogen in different percentages were slightly decreased soil $\mathrm{pH}$ and electrical conductivity $\left(\mathrm{EC} \mathrm{dSm} \mathrm{dS}^{-1}\right)$ compared with ammonium sulphate as a source of nitrogen only (Figures, 1B and 1C). The highest $\mathrm{pH}$ and electrical conductivity $\left(\mathrm{EC} \mathrm{dSm}{ }^{-1}\right)$ were recorded in $T_{1} \quad\left(100 \%\right.$ inorganic nitrogen) and $T_{2}$ $(66.6 \%$ inorganic nitrogen +33.3 organic nitrogen) with significant differences between them and other treatments. Treatments of $\mathrm{T}_{3}(50 \%$ inorganic nitrogen $+50 \%$ organic nitrogen), $\mathrm{T}_{4}$ (33.3 inorganic nitrogen +66.6 organic nitrogen) and $T_{5}(100 \%$ organic nitrogen) gave approximately the same values of $\mathrm{pH}$ and electrical conductivity (EC dSm$\left.{ }^{-1}\right)$ without significant differences among them. Similar results were obtained by Ferguson (1994) who revealed that, application of 10 and 20 ton per acre chicken manure led to decrease soil $\mathrm{pH}$ from 7.4 to 6.4 and 7.2 to 6.5 , respectively.

As shown in Figures (1D) and (1E), soil content of $\mathrm{NH}_{4}{ }^{+}-\mathrm{N}$ and $\mathrm{NO}_{3}{ }^{-}-\mathrm{N}$ were significantly affected by all treatments at the end of experiment. The combined application of 33.3 inorganic nitrogen + 66.6 organic nitrogen $\left(\mathrm{T}_{4}\right)$ had the highest value of $\mathrm{NH}_{4}{ }^{+}-\mathrm{N}$ and $\mathrm{NO}_{3}{ }^{-}-\mathrm{N}$ followed by application of $50 \%$ inorganic nitrogen + $50 \%$ organic nitrogen $\left(\mathrm{T}_{3}\right)$ and application of $66.6 \%$ inorganic nitrogen +33.3 organic nitrogen $\left(T_{2}\right)$, respectively. On contrary that, the lowest value of $\mathrm{NH}_{4}{ }^{+}-\mathrm{N}$ and $\mathrm{NO}_{3}^{-}-\mathrm{N}$ were observed on sole application of $100 \%$ organic nitrogen $\left(T_{5}\right)$. Similar results were obtained by Delgado et al., (2006) and Sainju et al., (2010).

The results in Figures (1F) and (1G) indicated that, heavy metals such $\mathrm{Pb}$ and Cd were significantly decreased with increasing percentages of poultry manure applications. Treatments of $\mathrm{T}_{5}$ $\left(100 \%\right.$ organic nitrogen), $\quad \mathrm{T}_{4} \quad(33.3$ inorganic nitrogen +66.6 organic nitrogen) and $\mathrm{T}_{3}(50 \%$ inorganic nitrogen $+50 \%$ organic nitrogen) led to reduce heavy metals content in the soil. The highest values of $\mathrm{Pb}$ and $\mathrm{Cd}$ were found in application of $100 \%$ inorganic nitrogen $\left(\mathrm{T}_{1}\right)$. On the other side, $\mathrm{Zn}$ was increased with increasing poultry manure level (Figure, 1H). These results are in harmony with those obtained by Ajayi et al., (2012) using different fertilizers in citrus and vegetable farms fertilization and they found that trace elements concentration in the soil was belonged to type fertilizer used and organic fertilizers reduce heavy metals.

Generally, it is clear from Figure (1) that, soil organic matter percentage, $\mathrm{pH}$, $\mathrm{EC}, \mathrm{NH}_{4}{ }^{+}-\mathrm{N}, \mathrm{NO}_{3}{ }^{-}-\mathrm{N}, \mathrm{Zn}, \mathrm{Pb}$ and $\mathrm{Cd}$ were positively affected by added poultry manure. Improving soil chemical properties have had a positive and significant impact on the nutritional status of trees, which are reflected on tree growth and production. This explain agree with those obtained by Ogundijo et al., (2014) they indicate that yield of some crops was increased with improving soil chemical properties by application of 10 ton/ hectare poultry manure. Moreover, soil $\mathrm{pH}$ and EC had positive and significant correlation with organic matter content in soil suggesting that increased organic matter led to decrease $\mathrm{pH}$ and EC in soil. On the other hand, organic matter, $\mathrm{NH}_{4}{ }^{+}-\mathrm{N}$ and $\mathrm{NO}_{3}{ }^{-}-\mathrm{N}$ contents were gradually increased with increasing poultry manure percentages fertilization in the soil. As for heavy metals, a negative and significant correlation was observed between organic fertilizer doses and heavy metals ( $\mathrm{Cd}$ and $\mathrm{Pb}$ ). Heavy metals decreased with the increase of organic fertilizer doses. These results are in agreement with findings of lbe et al., (2011) and Cerda et al., (2012). 
So, it can be concluded that, combined application of organic and inorganic nitrogen fertilizers improved the soil chemical properties especially $T_{4}$ (33.3 inorganic nitrogen +66.6 organic nitrogen) and $\mathrm{T}_{3}(50 \%$ inorganic nitrogen $+50 \%$ organic nitrogen) compared to other treatments. This is because poultry manure not only adds organic matter and macro and micronutrients to soil, but also improves the physical properties of soil. Moreover, availability of nitrogen $\left(\mathrm{NH}_{4}{ }^{+}-\mathrm{N}\right.$ and $\left.\mathrm{NO}_{3}{ }^{-}-\mathrm{N}\right)$ was increased with the increase of organic fertilizer, this is important for improvement tree growth and development as well as high yield. similar results were obtained by Sharma et al., (2016) who found that, application of $50 \%$ poultry manure $+\mathbf{5 0 \%}$ urea improved soil organic carbon $\%, N, P, C a$ and $\mathrm{Mg}$ after fruit harvest, increased leaf mineral content as well as gave best growth and highest fruit yield of Guava.

\section{Leaf mineral content:}

It is evident from data in Tables ( 3 and 4) that, application of recommended nitrogen through poultry manure and ammonium sulphate enhanced leaf mineral content of Washington navel orange trees. It is also clear that, Washington navel orange trees fertilized with $\mathrm{T}_{3}(50 \%$ inorganic nitrogen $+50 \%$ organic nitrogen), $\mathrm{T}_{4}$ (33.3\% inorganic nitrogen +66.6 organic nitrogen) and $T_{1}$ (100\% inorganic nitrogen) had higher $N$, $\mathrm{P}, \mathrm{K}$ and $\mathrm{Ca}$ than other treatments. The results show significant differences among treatments in both seasons as for $\mathrm{N}, \mathrm{P}, \mathrm{K}$ and $\mathrm{Ca}$, while the differences were not significant as for $\mathrm{Mg}$ in both seasons.

Table 3: Effect of organic and inorganic nitrogen fertilizers on leaf mineral content of Washington navel orange trees.

\begin{tabular}{|c|c|c|c|c|}
\hline \multirow{2}{*}{ Treatments } & \multicolumn{2}{|c|}{$\mathbf{N} \%$} & \multicolumn{2}{|c|}{$\mathbf{P} \%$} \\
\hline & 2017 & 2018 & 2017 & 2018 \\
\hline$T_{1}: 100 \%$ inorganic & $2.45 \mathrm{a}$ & $2.53 \mathrm{a}$ & $0.222 \mathrm{a}$ & $0.225 \mathrm{~b}$ \\
\hline $\mathrm{T}_{2}: 66.6 \%$ inorganic $+33.6 \%$ organic & $2.16 \mathrm{c}$ & $2.23 \mathrm{c}$ & $0.212 \mathrm{~b}$ & $0.218 \mathrm{c}$ \\
\hline $\mathrm{T}_{3}: \mathbf{5 0} \%$ inorganic $+\mathbf{5 0} \%$ organic & $2.35 \mathrm{~b}$ & $2.53 \mathrm{a}$ & $0.223 \mathrm{a}$ & $0.233 a$ \\
\hline $\mathrm{T}_{4}: 33.3 \%$ inorganic $+66.6 \%$ organic & $2.32 \mathrm{~b}$ & $2.44 \mathrm{~b}$ & $0.224 a$ & $0.219 \mathrm{c}$ \\
\hline$T_{5}: 100 \%$ organic & $2.11 \mathrm{c}$ & $2.17 \mathrm{~d}$ & $0.215 \mathrm{~b}$ & $0.218 \mathrm{c}$ \\
\hline \multirow{2}{*}{ Treatments } & \multicolumn{2}{|c|}{ K \% } & \multicolumn{2}{|c|}{$\mathrm{Ca} \%$} \\
\hline & 2017 & 2018 & 2017 & 2018 \\
\hline$T_{1}: 100 \%$ inorganic & $1.80 \mathrm{c}$ & $1.85 \mathrm{c}$ & $2.33 \mathrm{c}$ & $2.41 \mathrm{c}$ \\
\hline $\mathrm{T}_{2}: 66.6 \%$ inorganic $+33.6 \%$ organic & $1.84 \mathrm{bc}$ & $1.95 \mathrm{~b}$ & $2.35 \mathrm{c}$ & $2.43 \mathrm{c}$ \\
\hline $\mathrm{T}_{3}: 50 \%$ inorganic $+\mathbf{5 0} \%$ organic & $1.91 \mathrm{abc}$ & $2.07 \mathrm{a}$ & $2.71 \mathrm{~b}$ & $2.70 \mathrm{~b}$ \\
\hline $\mathrm{T}_{4}: 33.3 \%$ inorganic $+66.6 \%$ organic & $1.95 \mathrm{ab}$ & $2.10 \mathrm{a}$ & $2.79 \mathrm{~b}$ & $2.75 a b$ \\
\hline$T_{5}: 100 \%$ organic & $2.00 \mathrm{a}$ & $2.12 \mathrm{a}$ & $2.96 \mathrm{a}$ & $2.83 \mathrm{a}$ \\
\hline
\end{tabular}

Means followed by the same letter within a column are not significantly different using DMRT at $P \leq$ 0.05 
H. A. Ennab, et al.,

Table 4: Effect of organic and inorganic nitrogen fertilizers on leaf mineral content of Washington navel orange trees

\begin{tabular}{|l|c|c|c|c|}
\hline \multirow{2}{*}{ Treatments } & \multicolumn{2}{|c|}{ Mg \% } & \multicolumn{2}{c|}{ Fe ppm } \\
\cline { 2 - 5 } & 2017 & 2018 & 2017 & 2018 \\
\hline $\mathrm{T}_{1}: 100 \%$ inorganic & $0.44 \mathrm{a}$ & $0.44 \mathrm{a}$ & $50.25 \mathrm{c}$ & $57.63 \mathrm{~d}$ \\
$\mathrm{~T}_{2}: 66.6 \%$ inorganic $+33.6 \%$ organic & $0.43 \mathrm{a}$ & $0.43 \mathrm{a}$ & $55.91 \mathrm{c}$ & $65.76 \mathrm{c}$ \\
$\mathrm{T}_{3}: 50 \%$ inorganic $+50 \%$ organic & $0.45 \mathrm{a}$ & $0.44 \mathrm{a}$ & $70.27 \mathrm{~b}$ & $74.06 \mathrm{~b}$ \\
$\mathrm{~T}_{4}: 33.3 \%$ inorganic $+66.6 \%$ organic & $0.44 \mathrm{a}$ & $0.43 \mathrm{a}$ & $68.38 \mathrm{~b}$ & $72.27 \mathrm{~b}$ \\
$\mathrm{~T}_{5}: 100 \%$ organic & $0.44 \mathrm{a}$ & $0.43 \mathrm{a}$ & $85.28 \mathrm{a}$ & $90.29 \mathrm{a}$ \\
\hline \multirow{2}{*}{ Treatments } & \multicolumn{2}{|c|}{$\mathrm{Mn} \mathrm{ppm}$} & \multicolumn{2}{|c|}{$\mathrm{Zn} \mathrm{ppm}$} \\
\cline { 2 - 6 } & 2017 & $2018 / 19$ & 2017 & 2018 \\
\hline $\mathrm{T}_{1}: 100 \%$ inorganic & $28.00 \mathrm{~b}$ & $29.25 \mathrm{c}$ & $25.64 \mathrm{~d}$ & $24.83 \mathrm{c}$ \\
$\mathrm{T}_{2}: 66.6 \%$ inorganic $+33.6 \%$ organic & $27.83 \mathrm{~b}$ & $28.21 \mathrm{c}$ & $28.18 \mathrm{c}$ & $29.88 \mathrm{~b}$ \\
$\mathrm{~T}_{3}: 50 \%$ inorganic $+50 \%$ organic & $37.53 \mathrm{a}$ & $38.62 \mathrm{a}$ & $31.37 \mathrm{~b}$ & $32.46 \mathrm{ab}$ \\
$\mathrm{T}_{4}: 33.3 \%$ inorganic $+66.6 \%$ organic & $36.54 \mathrm{a}$ & $38.37 \mathrm{a}$ & $35.09 \mathrm{a}$ & $34.86 \mathrm{a}$ \\
$\mathrm{T}_{5}: 100 \%$ organic & $34.41 \mathrm{a}$ & $34.94 \mathrm{~b}$ & $35.81 \mathrm{a}$ & $35.79 \mathrm{a}$ \\
\hline
\end{tabular}

Means followed by the same letter within a column are not significantly different using DMRT at $P \leq$ 0.05

Moreover, treatments included poultry manure as organic fertilization especially $T_{5}\left(100 \%\right.$ organic nitrogen), $T_{4}(33.3 \%$ inorganic nitrogen +66.6 organic nitrogen) and $\mathrm{T}_{3}(50 \%$ inorganic nitrogen $+\mathbf{5 0} \%$ organic nitrogen) raised leaf $\mathrm{Fe}$, $\mathrm{Mn}$ and $\mathrm{Zn}$ content compared to other treatments and $100 \%$ mineral nitrogen only $\left(T_{1}\right)$. This may be due to organic fertilizer decomposition released; organic acids which decrease soil $\mathrm{pH}$ and increased $\mathrm{Fe}, \mathrm{Mn}, \mathrm{Zn}$ availability. These results were similar to those obtained by Mansour and Shaaban (2007) and Ahmed et al., (2017) who noted that leaf analysis of Washington navel orange and Kinnow trees showed a high level of N, P and $K$ when treated with organic nitrogen combined with dose of mineral nitrogen. Sharma et al., (2016) concluded that, soil application of $50 \% \mathrm{~N}$ poultry manure + $50 \% \mathrm{~N}$ urea on guava trees recorded the highest leaf $\mathrm{N}, \mathrm{P}, \mathrm{K}, \mathrm{Ca}$ and $\mathrm{Mg}$ compared with mineral nitrogen only. With regard to micronutrients, results in Table (4) showed that, leaf $\mathrm{Fe}, \mathrm{Mn}$ and $\mathrm{Zn}$ were improved with the application of poultry manure fertilizer. These results were similar with those reported by Ennab (2016) who revealed that Eureka lemon trees fertilized with a combination between farmyard manure and doses of mineral NPK had significantly effective in enhancing leaf $\mathrm{Fe}, \mathrm{Mn}$ and $\mathrm{Zn}$ contents compared to the application of mineral NPK only. So, nutrients content in leaves were significantly increased with organic manure fertilizers, especially application of poultry manure at 2.73 ton/feddan + $305.8 \mathrm{~kg} /$ feddan ammonium sulphate $\left(\mathrm{T}_{3}\right)$ and poultry manure at 3.64 ton/feddan poultry manure $+203.8 \mathrm{~kg} / \mathrm{feddan}$ ammonium sulphate( $\left(\mathrm{T}_{4}\right)$. In generally, it could be concluded from Figure (1) and Tables ( 3 and 4 ) that, application of poultry manure and dose of mineral nitrogen enhancing soil organic matter percentage, $\mathrm{pH}, \mathrm{EC}, \mathrm{NH}_{4}{ }^{+}-\mathrm{N}$ and $\mathrm{NO}_{3}{ }^{-}-\mathrm{N}$, and improving nutrient uptake of Washington navel orange trees. 


\section{Tree size and vegetative growth:}

Results presented in Figure (2) and Table (5) showed that, soil application of recommended nitrogen through poultry manure and dose of mineral nitrogen had a significant effect on tree size and vegetative growth parameters at the end of experiment. It is clear from Figure (2) that different treatments of organic and inorganic nitrogen fertilizers had a significantly influenced the tree height growth $\%$ and canopy volume growth\% of Washington navel orange. The maximum tree height growth\% and canopy volume growth \% were recorded under the soil application of $50 \%$ inorganic nitrogen + $50 \%$ organic nitrogen $\left(\mathrm{T}_{3}\right)$ followed by treatment $\mathrm{T}_{4}(33.3 \%$ inorganic nitrogen + $66.6 \%$ organic nitrogen), whereas the minimum tree height growth $\%$ and canopy volume growth \% were recorded with $\mathrm{T}_{1}\left(\mathbf{1 0 0 \%}\right.$ inorganic nitrogen) and $\mathrm{T}_{5}$ (100\% organic nitrogen). Similar results have been reported by Dahiya et al., (2013) and Ahmed et al., (2017). Also, Garhwal et al., (2014) show that application of $80 \mathrm{~kg}$ farm yard manure + $750 \mathrm{~g}$ nitrogen per tree significantly resulted in maximum increase in tree height and canopy volume of Kinnow mandarin tree.

Also, data in Table (5) indicated that, shoot number per branch, shoot length, leaves number per shoot and leaf area were significantly affected by various treatments in the present study. The highest values of vegetative growth parameters were obtained with $T_{1}(100 \%$ inorganic nitrogen) and $\mathrm{T}_{3}$ (50\% inorganic nitrogen $+\mathbf{5 0} \%$ organic nitrogen) without significant differences between them in both seasons. On contrary, using $100 \%$ organic nitrogen $\left(\mathrm{T}_{5}\right)$ produced the lowest significant values of vegetative growth parameters as compared to other treatments in both seasons. Whereas, the trees that received $\mathrm{T}_{2}(66.6 \%$ mineral nitrogen $+33.3 \%$ organic nitrogen) and $\mathrm{T}_{4}$ $(33.3 \%$ mineral nitrogen $+66.6 \%$ organic nitrogen) gave intermediate values of most vegetative growth parameters without significant differences between them in both seasons. Similar results were obtained by Barakat et al., (2012) and Lal and Dayal (2014) on citrus. In this respect, Khehra and Bal (2014) observed that, lemon trees fertilized with farmyard manure $150 \mathrm{Kg} /$ tree + inorganic fertilizer $525 \mathrm{~g} /$ tree + Azotobacter $18 \mathrm{~g} /$ tree proved to be most effective in improving vegetative growth in terms of plant height, canopy volume, trunk girth as compared to control treatment.

Generally, it is obvious from Figure (2) and Table (5) that, tree size and growth vigour of Washington navel orange were significantly enhanced by applying organic and inorganic nitrogen fertilization especially application of $\mathbf{2 . 7 3}$ ton/feddan poultry manure $+\mathbf{3 0 5 . 8}$ $\mathrm{kg} / \mathrm{feddan}$ ammonium sulphate $\left(\mathrm{T}_{3}\right)$ followed by application of 3.64 ton/feddan poultry manure +203.8 $\mathrm{kg} / \mathrm{feddan}$ ammonium sulphate $\left(\mathrm{T}_{4}\right)$. The obtained increase in vegetative growth as a result of $T_{3}$ and $T_{4}$ treatments maybe due to improved nutritional status and physical properties of the soil caused by the addition of poultry manure. This made the tree to uptake water and mineral nutrients better, resulting in its increased tree size and growth parameters. Moreover, poultry manure improves chemical properties of soil, which provides better conditions for tree growth and development. The findings are in line with the results obtained by $\mathrm{Li}$ et al., (2017) and our data in Figure (1). 


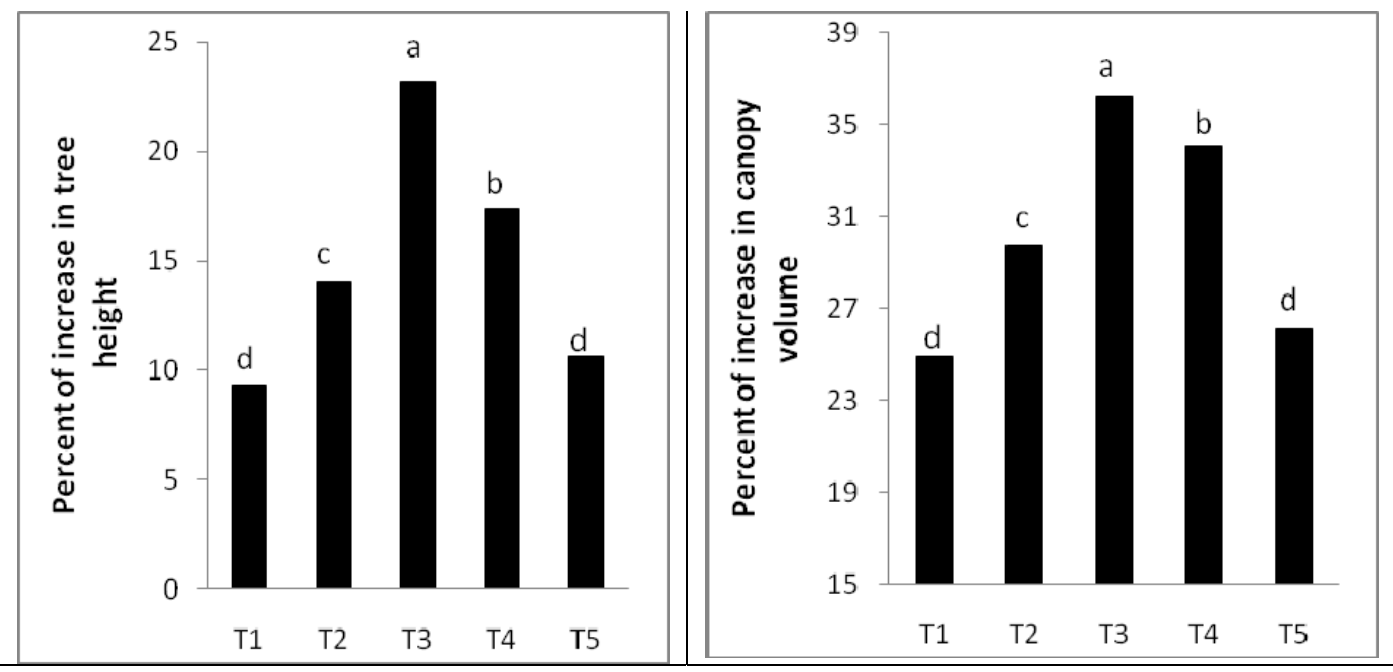

Figure 2. Effect of organic and inorganic nitrogen fertilizers on percent of increase in tree height and canopy volume at the end of experiment of Washington navel orange trees

( $\mathrm{T}_{1}: 100 \%$ inorganic; $\mathrm{T}_{2}: \mathbf{6 6 . 6 \%}$ inorganic $+33.6 \%$ organic; $\mathrm{T}_{3}: 50 \%$ inorganic $+50 \%$ organic; $\mathrm{T}_{4}$ : $33.3 \%$ inorganic $+66.6 \%$ organic; $\mathrm{T}_{5}: \mathbf{1 0 0} \%$ organic)

Table 5: Effect of organic and inorganic nitrogen fertilizers on some growth parameters of Washington navel orange trees

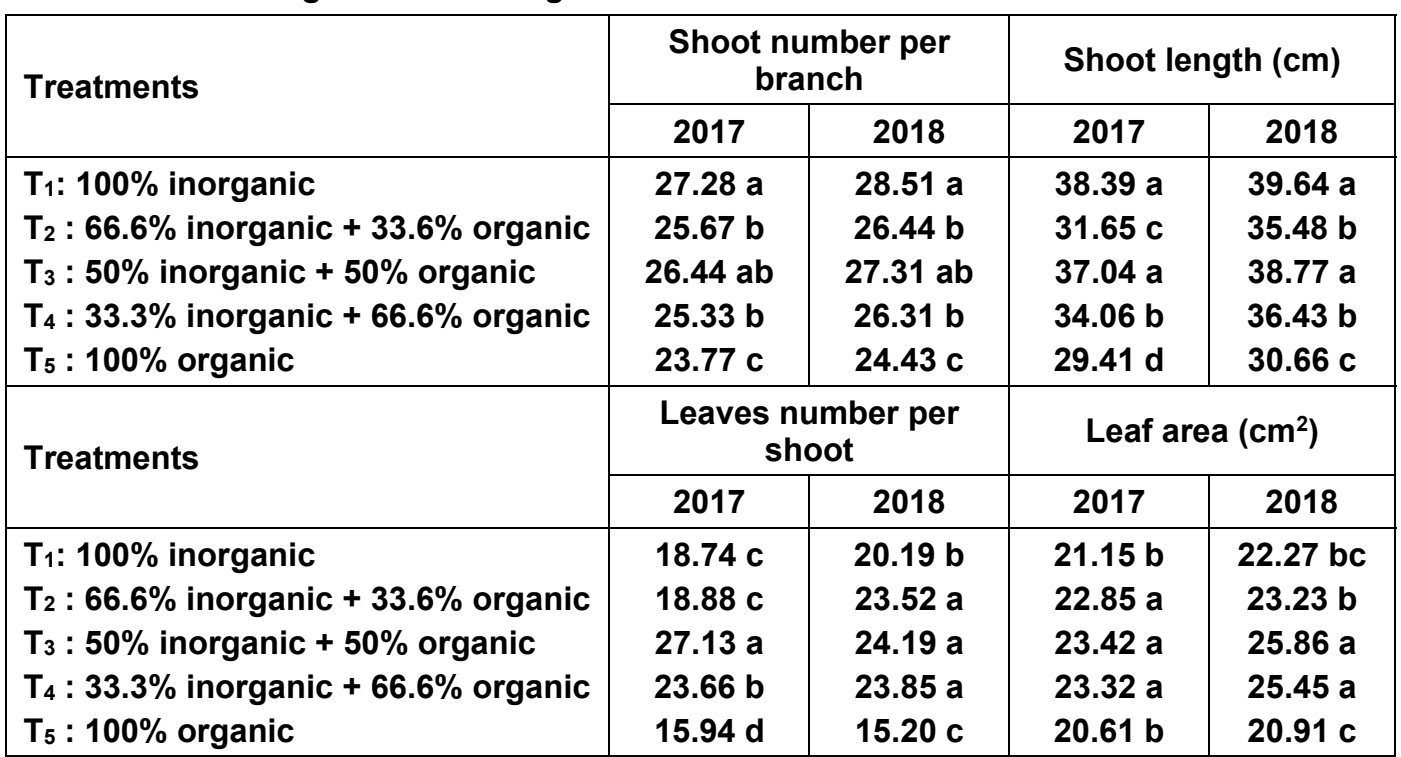

Means followed by the same letter within a column are not significantly different using DMRT at $P \leq$ 0.05

\section{Final fruit set and preharvest} fruit drop percentages:

It appeared from Figure (3) that, final fruit set and preharvest fruit drop percentages were significantly improved by the different fertilization treatments in both seasons. As for final fruit set percentage, its clear that, $\mathrm{T}_{3}(50 \%$ mineral 
nitrogen $+50 \%$ organic nitrogen), $\mathbf{T}_{4}$ $(33.3 \%$ mineral nitrogen $+66.6 \%$ organic nitrogen) and $T_{5}(100 \%$ organic nitrogen) exhibited the highest final fruit set in both seasons, respectively. The differences were not significant among them in both seasons. On the other hand, $\mathrm{T}_{1} \quad\left(100 \%\right.$ inorganic nitrogen) and $\mathrm{T}_{2}$ $(66.6 \%$ mineral nitrogen $+33.3 \%$ organic nitrogen) gave the lowest values of final fruit set percentage in both seasons. This may be due to organic fertilizer contain all the micronutrients essentially for trees in balanced state of and/or microorganisms included with organic fertilizer gave stimulating hormones cases improved fruit set and preharvest fruit drop. These results are in harmony with those obtained by Ahmed et al., (2013) and Ennab, (2016) on Balady mandarin and Eureka lemon. In this respect, El Aidy et al., (2018) revealed that application of half nutrient requirements as mineral NPK and the other half from organic source (compost) in combination with 150 or $200 \mathrm{ml}$ biofertilizers had positive effect on fruit set $\%$ of Valencia orange trees as compared with mineral fertilizers only. Also, the data illustrated in Figure (3) cleared that, the lowest percentages of preharvest fruit drop were found on trees fertilized by $T_{3}, T_{4}$ and $T_{5}$ in both seasons. On contrary, the highest fruit drop percentage was observed on treatment $T_{1}$ and $T_{2}$ respectively. Similar results were obtained by El Saady and El-Abd, (2012) and Ahmed et al., (2013) they reported that organic, biofertilizers and NPK alone or combined together significantly decreased the percentages of June drop and preharvest drop in navel orange trees.

So, it can be concluded that, final fruit set and preharvest fruit drop of Washington navel orange trees were positively affected by organic nitrogen as poultry manure with doses of mineral nitrogen fertilizers in both seasons. In this respect, organic and inorganic nitrogen gave the best fruit set and also reduced fruit drop especially $\mathrm{T}_{4}$ and $\mathrm{T}_{3}$ compared to other treatments.

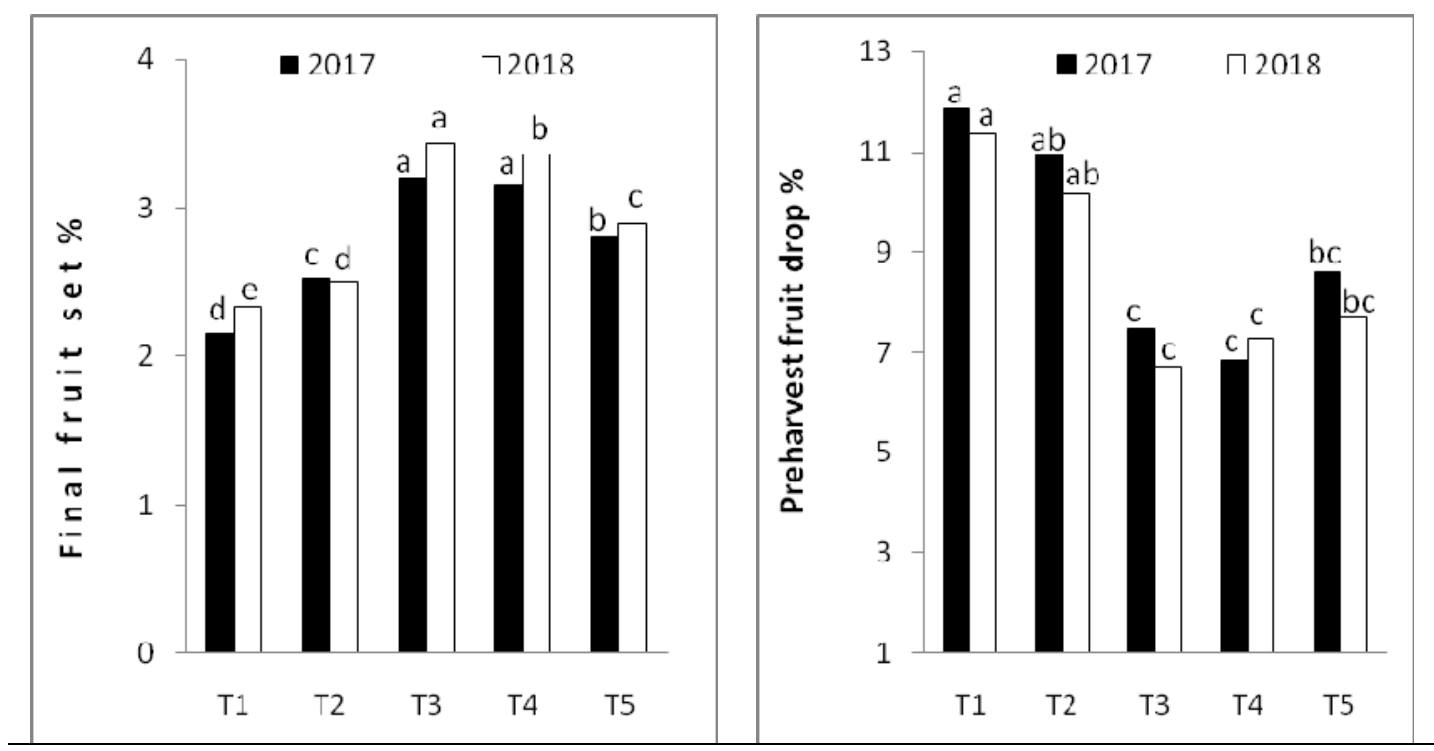

Figure (3). Effect of organic and inorganic nitrogen fertilizers on final fruit set and preharvest fruit drop percentages of Washington navel orange trees.

( $\mathrm{T}_{1}: \mathbf{1 0 0 \%}$ inorganic; $\mathrm{T}_{2}: \mathbf{6 6 . 6 \%}$ inorganic $+33.6 \%$ organic; $\mathrm{T}_{3}: 50 \%$ inorganic $+50 \%$ organic; $\mathrm{T}_{4}: 33.3 \%$ inorganic $+66.6 \%$ organic; $\mathrm{T}_{5}: \mathbf{1 0 0} \%$ organic) 
5. Yield:

Results in Table (6) showed that, application of poultry manure with nitrogen dose were significantly increased fruit yield of Washington navel orange trees expressed as number of fruits/tree and $\mathrm{kg} /$ tree in both seasons. Treatments of $\mathrm{T}_{3}(50 \%$ inorganic nitrogen $+50 \%$ organic nitrogen) and $\mathrm{T}_{4}(33.3 \%$ inorganic nitrogen $+66.6 \%$ organic nitrogen) tended to gave the highest values of yield as number of fruits/tree and $\mathrm{kg} / \mathrm{tree}$ without significant differences between them in both seasons. On contrary, using 100\% inorganic nitrogen $\left(T_{1}\right)$ produced the lowest values of yield in both seasons. In this respect, $T_{5}(100 \%$ organic nitrogen) produced moderate yield in both seasons. These results are in agreement with those obtained by El Aidy et al., (2018). In this respect, Garhwal et al., (2014) on Kinnow mandarin, they reported that, number of fruits per tree and average weight of fruits significantly increased with application of farmyard manure and doses of mineral nitrogen as compared with mineral nitrogen only. Also, Ennab et al., (2018) revealed that Costata persimmon tree fertilized with $50 \%$ mineral nitrogen plus $25 \%$ organic manure $+25 \mathrm{~g} /$ tree biofertilizers bearing higher yield (kg/tree) than that fertilized with $100 \%$ mineral nitrogen only. The beneficial effect of organic and inorganic nitrogen fertilizers on improving yield of Washington navel orange trees maybe due to positive effect on nutrients uptake (Tables 3 and 4) which reflected on active vegetative growth parameters in Figure (2) and Table (5). Also the positive response of yield as a result of poultry manure treatments maybe due to increase soil organic matter, increase soil microorganisms activities, thus it can fix atmospheric nitrogen, increase phosphorus availability in soil and enhanced elements uptake by
Washington navel orange tree, that reflected to tree's ability to grow and increase productivity. Also, yield was increase as a result of increasing fruit set and decreasing fruit drop percentages. This conclusion agrees with the result obtained by Ennab, (2016) and our data in Figure (3).

\section{Fruit quality:}

\subsection{Physical characters:}

Data in Table 7 show the effect of organic and inorganic nitrogen fertilizers on physical fruit quality in terms of fruit weight, size, juice \% and fruit firmness of Washington navel orange trees in both seasons. Trees fertilized with $\mathrm{T}_{3} \quad(50 \%$ inorganic nitrogen $+\mathbf{5 0 \%}$ organic nitrogen), $\mathrm{T}_{4}$ (33.3\% inorganic nitrogen + $66.6 \%$ organic nitrogen) and $T_{2}(66.6 \%$ inorganic nitrogen $+33.3 \%$ organic nitrogen) had the highest fruit juice content as well as the largest and heaviest fruit without significant differences among them in both seasons. With regard the effect of treatments on fruit firmness, $\mathrm{T}_{4} \quad(33.3 \%$ inorganic nitrogen $+66.6 \%$ organic nitrogen) and $T_{5}$ (100\% organic nitrogen) gave the highest values of fruit firmness in both seasons. Whereas, $T_{1}$ (100\% mineral nitrogen) gave the least values of fruit weight, size, juice $\%$ and firmness with significant differences between $T_{1}$ and other treatments in most cases in both seasons. These results agree with those obtained by Abd EI Migeed et al., (2007), Ahmed et al., (2013) and Ibrahim and Maklad, (2014). Generally, it is clear from Table 7 that, high juice quantity as well as heaviest and largest fruits with a good fruit firmness were harvested from trees that treated by $\mathrm{T}_{3}(50 \%$ inorganic nitrogen $+50 \%$ organic nitrogen) and $\mathrm{T}_{4}(33.3 \%$ inorganic nitrogen $+66.6 \%$ organic nitrogen) in both seasons. 
Table 6: Effect of organic and inorganic nitrogen fertilizers on yield of Washington navel orange trees

\begin{tabular}{|l|c|c|c|c|}
\hline \multirow{2}{*}{ Treatments } & \multicolumn{2}{|c|}{ No. of fruits/tree } & \multicolumn{2}{c|}{ Yield as kg/tree } \\
\cline { 2 - 5 } & 2017 & 2018 & 2017 & 2018 \\
\hline $\mathrm{T}_{1}: 100 \%$ inorganic & $279.15 \mathrm{~b}$ & $273.37 \mathrm{~d}$ & $62.58 \mathrm{c}$ & $65.25 \mathrm{c}$ \\
$\mathrm{T}_{2}: 66.6 \%$ inorganic $+33.6 \%$ organic & $290.74 \mathrm{~b}$ & $286.29 \mathrm{c}$ & $79.85 \mathrm{~b}$ & $79.86 \mathrm{~b}$ \\
$\mathrm{~T}_{3}: 50 \%$ inorganic $+50 \%$ organic & $323.73 \mathrm{a}$ & $322.63 \mathrm{a}$ & $90.02 \mathrm{a}$ & $91.87 \mathrm{a}$ \\
$\mathrm{T}_{4}: 33.3 \%$ inorganic $+66.6 \%$ organic & $315.65 \mathrm{a}$ & $322.54 \mathrm{a}$ & $86.38 \mathrm{a}$ & $90.43 \mathrm{a}$ \\
$\mathrm{T}_{5}: 100 \%$ organic & $290.44 \mathrm{~b}$ & $298.73 \mathrm{~b}$ & $66.87 \mathrm{c}$ & $73.41 \mathrm{bc}$ \\
\hline
\end{tabular}

Means followed by the same letter within a column are not significantly different using DMRT at $P \leq 0.05$

Table 7: Effect of organic and inorganic nitrogen fertilizers on physical fruit quality of Washington navel orange trees

\begin{tabular}{lcccc}
\hline \multirow{2}{*}{ Treatments } & \multicolumn{2}{c}{ Fruit weight $(\mathrm{g})$} & \multicolumn{2}{c}{ Fruit size $\left(\mathrm{cm}^{3}\right)$} \\
\cline { 2 - 5 } & 2017 & 2018 & 2017 & 2018 \\
\hline $\mathrm{T}_{1}: 100 \%$ inorganic & $223.49 \mathrm{~b}$ & $238.68 \mathrm{~b}$ & $236.78 \mathrm{C}$ & $261.40 \mathrm{c}$ \\
$\mathrm{T}_{2}: 66.6 \%$ inorganic $+33.6 \%$ organic & $274.65 \mathrm{a}$ & $278.48 \mathrm{a}$ & $299.34 \mathrm{a}$ & $305.19 \mathrm{a}$ \\
$\mathrm{T}_{3}: 50 \%$ inorganic $+50 \%$ organic & $278.06 \mathrm{a}$ & $284.74 \mathrm{a}$ & $303.06 \mathrm{a}$ & $312.04 \mathrm{a}$ \\
$\mathrm{T}_{4}: 33.3 \%$ inorganic $+66.6 \%$ organic & $273.67 \mathrm{a}$ & $280.38 \mathrm{a}$ & $298.27 \mathrm{a}$ & $307.26 \mathrm{a}$ \\
$\mathrm{T}_{5}: 100 \%$ organic & $230.00 \mathrm{~b}$ & $246.60 \mathrm{~b}$ & $250.68 \mathrm{~b}$ & $270.24 \mathrm{~b}$ \\
\hline & \multicolumn{2}{c}{ Juice \% } & Fruit firmness $\left(\mathrm{kg} / \mathrm{cm}^{2}\right)$ \\
\hline \multirow{2}{yyyyy}{ Treatments } & 2017 & 2018 & 2017 & 2018 \\
\hline $\mathrm{T}_{1}: 100 \%$ inorganic & $66.00 \mathrm{~b}$ & $57.69 \mathrm{c}$ & $55.17 \mathrm{e}$ & $59.34 \mathrm{e}$ \\
$\mathrm{T}_{2}: 66.6 \%$ inorganic $+33.6 \%$ organic & $81.16 \mathrm{a}$ & $78.68 \mathrm{a}$ & $72.83 \mathrm{~d}$ & $77.26 \mathrm{c}$ \\
$\mathrm{T}_{3}: 50 \%$ inorganic $+50 \%$ organic & $82.14 \mathrm{a}$ & $80.55 \mathrm{a}$ & $84.75 \mathrm{~b}$ & $85.33 \mathrm{a}$ \\
$\mathrm{T}_{4}: 33.3 \%$ inorganic $+66.6 \%$ organic & $80.71 \mathrm{a}$ & $79.15 \mathrm{a}$ & $91.46 \mathrm{a}$ & $79.86 \mathrm{~b}$ \\
$\mathrm{~T}_{5}: 100 \%$ organic & $67.90 \mathrm{~b}$ & $69.41 \mathrm{~b}$ & $78.80 \mathrm{c}$ & $85.52 \mathrm{a}$ \\
\hline
\end{tabular}

Means followed by the same letter within a column are not significantly different using DMRT at $P \leq 0.05$

\subsection{Chemical characters:}

6.2.1. SSC \%, acidity \% SSC/acid ratio and vitamin C:

Results in Table 8 showed that, organic and inorganic nitrogen fertilizers had significantly effect on chemical fruit quality in terms of SSC \%, acidity \% SSC/acid ratio and vitamin $\mathrm{C}$ of Washington navel oranges on both seasons. Fertilization of Washington navel orange trees with $\mathrm{T}_{3}(\mathbf{5 0} \%$ inorganic nitrogen $+\mathbf{5 0} \%$ organic nitrogen) produced fruits which had the highest
SSC $\%$, SSC/acid ratio and vitamin C and lowest acidity followed by $T_{5} \quad(100 \%$ organic nitrogen) and $\mathrm{T}_{4}(33.6 \%$ inorganic nitrogen $+66.6 \%$ organic nitrogen) in both seasons. Whereas, $\mathrm{T}_{1} \quad(100 \%$ inorganic nitrogen) gave the lowest values of SSC\%, SSC/acid ratio and vitamin $C$ and the highest values of acidity in both seasons. These results agree with those obtained by Mansour and Shaaban, (2007) and Ahmed et al., (2017). 
H. A. Ennab, et al.,

Table 8: Effect of organic and inorganic nitrogen fertilizers on chemical fruit quality of Washington navel orange trees

\begin{tabular}{lcccc}
\hline \multirow{2}{*}{ Treatments } & \multicolumn{2}{c}{ SSC $\%$} & \multicolumn{2}{c}{ Acidity $\%$} \\
\cline { 2 - 5 } & 2017 & 2018 & 2017 & 2018 \\
\hline $\mathrm{T}_{1}: 100 \%$ inorganic & $10.75 \mathrm{c}$ & $10.35 \mathrm{c}$ & $1.18 \mathrm{a}$ & $1.16 \mathrm{a}$ \\
$\mathrm{T}_{2}: 66.6 \%$ inorganic $+33.6 \%$ organic & $11.55 \mathrm{~b}$ & $11.18 \mathrm{~b}$ & $1.14 \mathrm{~b}$ & $1.14 \mathrm{~b}$ \\
$\mathrm{~T}_{3}: 50 \%$ inorganic $+50 \%$ organic & $12.15 \mathrm{a}$ & $11.61 \mathrm{a}$ & $1.12 \mathrm{bc}$ & $1.13 \mathrm{~b}$ \\
$\mathrm{~T}_{4}: 33.3 \%$ inorganic $+66.6 \%$ organic & $11.49 \mathrm{~b}$ & $11.14 \mathrm{~b}$ & $1.11 \mathrm{c}$ & $1.11 \mathrm{c}$ \\
$\mathrm{T}_{5}: 100 \%$ organic & $11.77 \mathrm{~b}$ & $11.50 \mathrm{a}$ & $1.10 \mathrm{c}$ & $1.11 \mathrm{c}$ \\
\hline & \multicolumn{5}{c}{$\mathrm{SSC} / \mathrm{acid}$ ratio } & Vitamin C $\mathrm{mg} / 100 \mathrm{ml}$ \\
\cline { 2 - 5 } Treatments & 2017 & 2018 & 2017 & 2018 \\
\hline $\mathrm{T}_{1}: 100 \%$ inorganic & $9.11 \mathrm{e}$ & $8.93 \mathrm{~d}$ & $54.93 \mathrm{a}$ & $52.33 \mathrm{bc}$ \\
$\mathrm{T}_{2}: 66.6 \%$ inorganic $+33.6 \%$ organic & $10.13 \mathrm{~d}$ & $9.80 \mathrm{c}$ & $55.78 \mathrm{a}$ & $54.96 \mathrm{ab}$ \\
$\mathrm{T}_{3}: 50 \%$ inorganic $+50 \%$ organic & $10.84 \mathrm{a}$ & $10.27 \mathrm{a}$ & $53.86 \mathrm{ab}$ & $56.61 \mathrm{a}$ \\
$\mathrm{T}_{4}: 33.3 \%$ inorganic $+66.6 \%$ organic & $10.32 \mathrm{c}$ & $10.01 \mathrm{~b}$ & $50.23 \mathrm{~b}$ & $49.57 \mathrm{c}$ \\
$\mathrm{T}_{5}: 100 \%$ organic & $10.67 \mathrm{~b}$ & $10.36 \mathrm{a}$ & $53.14 \mathrm{ab}$ & $50.45 \mathrm{c}$ \\
\hline
\end{tabular}

Means followed by the same letter within a column are not significantly different using DMRT at $P \leq 0.05$

\subsubsection{Nitrate and nitrite contents:}

Results in Figure 4 revealed that, fruit juice nitrate and nitrite contents were significantly decreased by using different combination treatments as average of both seasons comparing with $100 \%$ mineral nitrogen, which gave the highest values of nitrate and nitrite contents followed by $\mathrm{T}_{2}(66.6 \%$ mineral nitrogen + $33.3 \%$ organic nitrogen). Meanwhile, trees fertilized by $\mathrm{T}_{3}, \mathrm{~T}_{4}$ and $\mathrm{T}_{5}$ produced fruits with low nitrate and nitrite contents (Figure 4). These results are in line with those obtained by Abd El Migeed et al., (2007), Ahmed et al., (2013) and Ennab et al., (2018). They concluded that, trees fertilizing by organic, biofertilizers with $50 \%$ doses of mineral nitrogen led to reduced nitrate and nitrite values in fruit juice comparing with $100 \%$ mineral nitrogen fertilizer. This conclusion agrees with our results in Figure $\mathbf{4}$ which cleared that nitrate and nitrite in fruit juice were gradually decreased with increasing organic fertilizers percentages to replacing mineral nitrogen fertilization. This phenomenon was much pronounced in treatments of $T_{3}, T_{4}$ and $T_{5}$ which had a beneficial effect on reducing nitrate and nitrite in fruit juice.

Generally, it is obvious from Tables 2 and 3 and Figure 1 that, application of recommended nitrogen fertilization through poultry manure and doses of mineral nitrogen are able to consistently improve fruit quality in terms of fruit weight, size, juice quantity, length, firmness, SSC, acidity, SSC/acid ratio, vitamin $C$, nitrate and nitrite of Washington navel oranges compared to mineral nitrogen only. In this respect, Washington navel orange trees received $305.8 \mathrm{~kg} / \mathrm{feddan}$ ammonium sulphate + 2.73 ton/feddan poultry manure $\left(\mathrm{T}_{3}\right)$ produced best fruit quality such high juice quantity as well as heaviest and largest fruits with a good fruit firmness compared to other treatments. This treatment also increased SSC\%, SSC/acid ratio and vitamin $\mathrm{C}$ and reducing acidity, nitrate and nitrite in fruit juice. These results agree with those obtained by Abd El Migeed et al., (2007), Sharma et al., (2016) and El Aidy et al., (2018). 


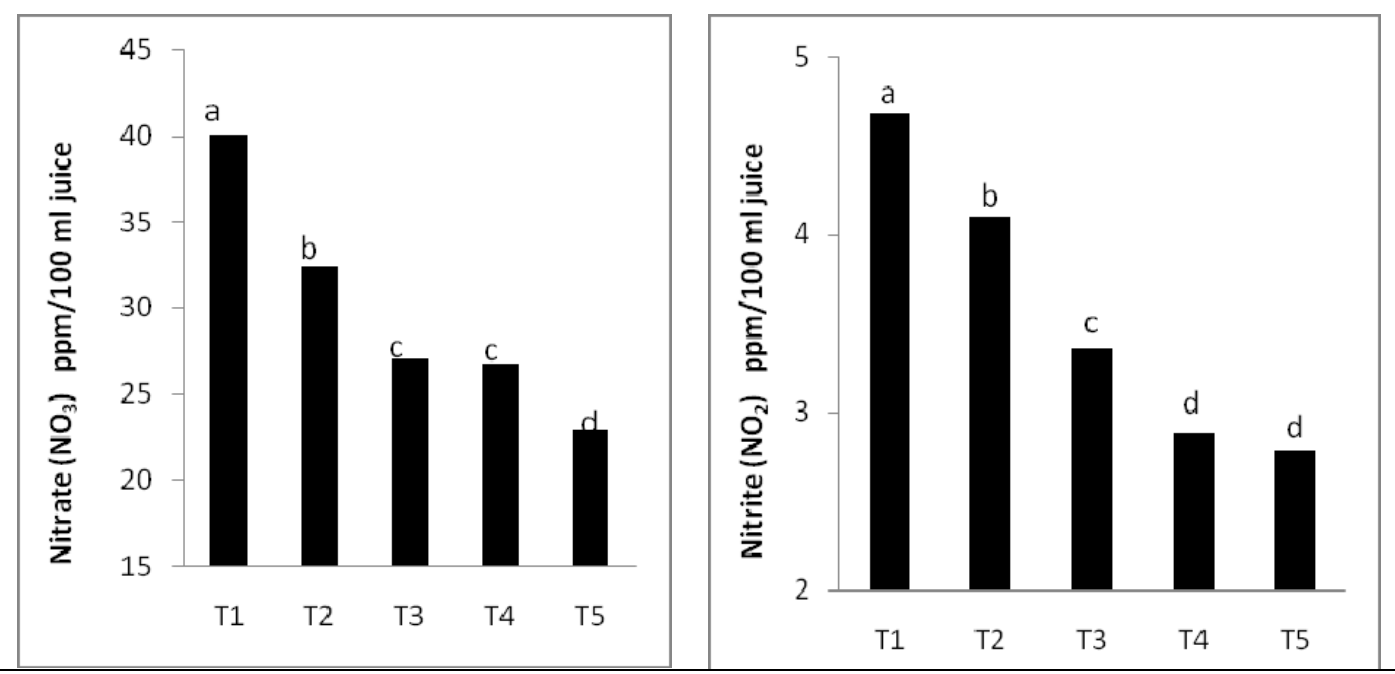

Figure 4. Effect of organic and inorganic nitrogen fertilizers on average values of both seasons of nitrate and nitrite in fruit juice $\mathrm{ppm} / 100 \mathrm{ml}$ juice of Washington navel oranges

( $\mathrm{T}_{1}: \mathbf{1 0 0 \%}$ inorganic; $\mathrm{T}_{2}: \mathbf{6 6 . 6 \%}$ inorganic $+33.6 \%$ organic; $\mathrm{T}_{3}: \mathbf{5 0 \%}$ inorganic $+\mathbf{5 0 \%}$ organic; $\mathrm{T}_{4}: 33.3 \%$ inorganic $+66.6 \%$ organic; $\mathrm{T}_{5}: 100 \%$ organic)

\section{Conclusion}

Consequently from the previously mentioned results, it was clear the main role of organic nitrogen with different doses of mineral nitrogen on Washington navel orange trees grown in clay soil, for supply nitrogen which indispensable for improvement of growth and the nutritional status of the Washington navel orange trees and production of maximum yield. Also, combined of organic and inorganic nitrogen could compensate $50 \%$ of mineral nitrogen without significant reduction in yield. Data also indicated that application of organic poultry manure resulted in significant decrease in $\mathrm{pH}$, electrical conductivity, $\mathrm{Cd}$ and $\mathrm{Pb}$, whereas, increase organic matter, $\mathrm{NH}_{4}{ }^{+}, \mathrm{NO}_{3}{ }^{-}$and $\mathrm{Zn}$ in soil. Therefore, this treatment is recommended $(50 \%$ mineral nitrogen + $\mathbf{5 0 \%}$ organic nitrogen). This improved soil chemical properties and gave the best growth, yield, fruit quality and nutritional status of Washington navel orange trees.

\section{REFERENCES}

A.O.A.C. (1990). Association of official analytical chemists. Official Methods of Analysis. 15th Ed. Washington D.C., USA.

Abd El Migeed, M.M., M.M. Saleh and E.A. Mostafa (2007). The beneficial effect of minimizing mineral nitrogen fertilization on Washington navel orange trees by using organic and biofertilizers. World J. Agric. Sci., 3(1):80 - 85 .

Ahmad, S., M.M. Naeem, M.M. Malik, M. Nafees and M. Yaseen (2017). Integrated nutrient management for better quality and yield of Kinnow mandarin. Journal of Plant Nutrition 40(6): 755 - 760.

Ahmed, F.F., A.H. Abdelaal and M.H. Faraag (2013). Partial replacement of inorganic $\mathbf{N}$ fertilizer in Balady mandarin orchards by using organic and biofertilization. Stem 4(2): 21 - 28.

Ajayi, S.O., B.O. Odesanya, A.O. Avwioroko, G.S. Adebambo and B. 
Okafor (2012). Effects of long term fertilizer use on trace metal levels of soils in a farm settlement. Journal of Agricultural Research and Development 2(2):44 - 51.

Amanullah, M.M., E. Somasundaram, K. Vaiyapuri and K. Sathyamoorthi (2007). Poultry manure to crops - a review. Agric. Rev., 28 (3): 216 - 222.

Bakshi, M., V.K. Wali, A. Sharma and V. Raina (2018). Economic evaluation of Kinnow mandarin cultivation using inorganic and organic nutrient sources along with biofertilizers. International Journal of Current Microbiology and Applied Sciences 7(8): $130-138$.

Barakat, M.R., T.A. Yehia and B.M. Sayed (2012). Response of Newhall naval orange to bio-organic fertilization under newly reclaimed area conditions I: Vegetative growth and nutritional status. J. Hort. Sci. \& Ornamen. Plants, 4(1): 18 - 25.

Brown, J.D. and O. Lillelland (1974). Rapid determination of potassium and sodium in plant material and soil extracts by flame photometer. Proc. Soc. Hort. Sci., 48: 341-346.

Camargo, J.A. and A. Alonso (2006). Ecological and toxicological effects of inorganic nitrogen pollution in aquatic ecosystems: A global assessment. Environment International 32: 831 849.

Canali, S., A. Trinchera, F. Intrigliolo, L. Pompili, L. Nisini, S. Mocali and B. Torrisi (2004). Effect of long term addition of composts and poultry manure on soil quality of citrus orchards in southern Italy. Biology and Fertility of Soils. 40(3): $206-210$.

Castle, W. (1983). Growth, yield and cold hardiness of seven year old 'Bearss' lemon on twenty seven rootstocks. Proc. Florida Sta. Hort. Soc. 96: 23-25.
Cerda, J.M., H.R. Perez, A.G. Diez, E.O. Saenz and J.A. Ruiz (2012). Effect of organic and synthetic fertilization in grapefruit (Citrus paradasi Macf.) yield and juice quality. Journal of Horticulture and Forestry 4(3):61 - 64.

Chapman, H.D. and P.F. Pratt (1961). Methods of Analysis for Soils, Plant and Waters. Univ. of California, USA, pp. 169-170.

Dahiya, S.S., S. Singh and R.P. Dalal (2013). Studies on the effect of organic manure versus organic plus inorganic fertilizers in sweet orange (Citrus sinensis Osbeck) cv. Jaffa. Haryana J. Hort. Sci., 42(1/2): 9 - 12.

Delgado, M., J.V. Martín and R. Miralles de Imperial (2006). Study of poultry manure to use in agriculture. American Society of Agricultural and Biological Engineers, St. Joseph, Michigan www.asabe.org (doi: 10.13031/2013.20940).

Duncan, D.B. (1955). Multiple range and multiple F. test. Biometries.11: 1 - 42.

El Aidy, A.A., S.M. Alam El Dein and W.M. Esa (2018). Effect of organic and biofertilizers on vegetative growth, yield and fruit quality of Valencia orange trees. J. Product. \& Dev., 23(1): 111 - 134.

El Saady, A.S. and A.A. Al-Abd (2012). Effect of balanced fertilizer splitting on navel orange yield and fruit quality. J. Soil Sci. and Agric. Eng., Mansoura Univ., 3(1):41 - 51.

Ennab, H.A. (2016). Effect of organic manures, biofertilizers and NPK on vegetative growth, yield, fruit quality and soil fertility of Eureka lemon trees (Citrus limon (L.) Burm). J. Soil Sci. and Agric. Eng., Mansoura Univ., 7(10):767 - 774.

Ennab, H.A., M.A.M. Soliman and G.B. Mikhael (2018). Replacing nitrogen fertilization by using organic and 
biofertilizers on Costata persimmon trees. J. Product. \& Dev., 23(1):39 - 59.

Evenhuis, B. and P.W. DeWaard (1980). Principles and practices in plant analysis. FAO soils Bull. 38:152 - 163.

Ferguson, J.J. (1994). Growth and yield of bearing and nonbearing citrus trees fertilized with fresh and processed chicken manure. Proc. Fla. State Hort. Soc., 107:29 - 32.

Fernandes, M.S. and R.O.P. Rossiello (1995). Mineral nitrogen in plant physiology and plant nutrition. Critical Reviews in Plant Sciences, 14(2): 111 $-148$.

Garhwal, P.C., P.K. Yadav, B.D. Sharma, R.S. Singh and A.S. Ramniw (2014). Effect of organic manure and nitrogen on growth, yield and quality of Kinnow mandarin in sandy soils of hot arid region. African J. Agric. Res., 9(34):2638 - 2647.

Ibe, R.B., I.O. Lawal and A.A. Olaniyan (2011). Economic analysis of yields of citrus as influenced by organo mineral fertilizer treatments in Ibadan, Southwest Nigeria. World Journal of Agricultural Sciences 7 (4): 425 - 429.

Ibrahim, A.M. and M.F. Maklad (2014). Effect of partial replacement of mineral nitrogen fertilization by organic from on yield and leaf mineral content of navel orange trees. J. Biol. Chem. Environ. Sci., 9(4):176 - 186.

Khehra, S. and J.S. Bal (2014). Influence of organic and inorganic nutrient sources on growth of lemon (Citrus limon (L.) Burm.) cv. Baramasi. J. Exp. Bio. and Agri. Sci., 2(1S): 126 - 129.

Kobierski, M., A. Bartkowiak, J. Lemanowicz and M. Piekarczyk (2017). Impact of poultry manure fertilization on chemical and biochemical properties of soils. Plant Soil Environ, 63(12): 558 - 563.
Lal, G. and H. Dayal (2014). Effect of integrated nutrient management on yield and fruit quality of acid lime (Citrus aurantifolia Swingle) Afr. J. Agric. Res., 9(40):2985 - 2991.

Li, R.F., Y. Chang, T. Hu, X. Jiang, G. Liang, Z. Lu, Y. Yi and Q. Guo (2017). Effects of different fertilization treatments on soil, leaf nutrient and fruit quality of Citrus grandis var. longanyou. World Journal of Engineering and Technology, 5: 1 14. (DOI: 10.4236/wjet.2017.52B001)

Mansour, A.E.M. and E.A. Shaaban (2007). Effect of different sources of mineral $\mathbf{N}$ applied with organic and bio fertilizers on fruiting of Washington navel orange trees. Journal of Applied Sciences Research, 3(8):764 - 769.

Murphy, J. and J.R. Riley (1962). A modified single solution method for the determination of phosphorus in natural water. Anal. Chem., Acta, 27: 31-38.

Nahm, K.H. (2003). Evaluation of the nitrogen content in poultry manure. World's Poultry Science Journal, 59:77 $-88$.

Ogundijo, D.S., M.T. Adetunji, J.O. Azeez and T.A. Arowolo (2014). Effect of organic and inorganic fertilizers on soil organic carbon, $\mathrm{pH}$, ammoniumnitrogen, nitrate-nitrogen and some exchangeable cations. Inter. J. Environ. Sci., 3(4):243 - 249.

Page, A.L., R.H. Miller and D.R. Keeney (1982). Methods of soil analysis part 2: chemical and microbiological properties second edition. Agronomy 920 Am. Soc. Agron. Inc. Soil Sci. Soc. Am. Inc. Pub. Madison, Wisconsin, USA.

Pregl, F. (1945). Quantitative organic microanalysis, $4^{\text {th }}$ ed J.A. Churchill, Ltd, London. 
Rapisarda, P., F. Camin, S. Fabroni, M. Perini, B. Torrisi and F. Intrigliolo (2010). Influence of different organic fertilizers on quality parameters and the values of orange fruit (Citrus sinensis L. Osbeck). J. Agric. Food Chem. 58:3502 - 3506.

Sainju, U.M., Z.N. Senwo, E.Z. Nyakatawa, I.A. Tazisong and K.C. Reddy (2010). Poultry litter application increases nitrogen cycling compared with inorganic nitrogen fertilization. Agronomy Journal 102(3):917 - 925.

Sharma, A., V.K. Wali, P. Bakshi, V. Sharma, V. Sharma, M. Bakshi and S. Rani (2016). Impact of poultry manure on fruit quality attributes and nutrient status of guava (Psidium guajava) cv.
L 49 plant. Indian Journal of Agricultural Sciences 86 (4):533 - 40.

Snedecor, G.W. and W.G. Cochran (1990). Statistical methods. 7th Ed. lowa State Univ. Press. Ames., lowa, USA, p. 593.

Wilde, S. A., R.B. Corey, J.G. Layer and G.K. Voigt (1985). Soils and plant analysis for tree culture. 3rd Ed. Oxford and IBH publishing Co., New Delhi, India. pp. 529 - 546.

Wong, H., J. Gao, X. Li, S. Zhang and H. Wang (2015). Nitrate accumulation and leaching in surface and groundwater based on simulated rainfall experiments PLoS ONE 10(8): e0136274. doi: 10.1371/ journal. pone. 0136274 
تأثير الأسمدة النيتروجينية العضوية والمعدنية على أثجار البرتقال أبو سرة

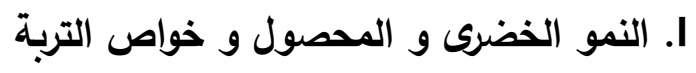

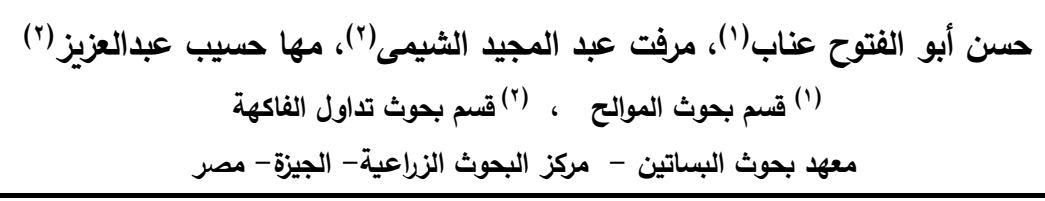

الملخص العربى

سبلة الدواجن لها تأثير مفيد على خصوبة التربة حيث ترفع مستوى المغنيات فى التربة و تعمل على تحسين ظروف التحبة التربة

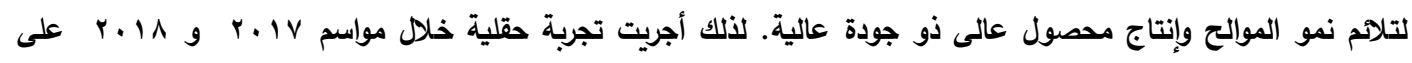

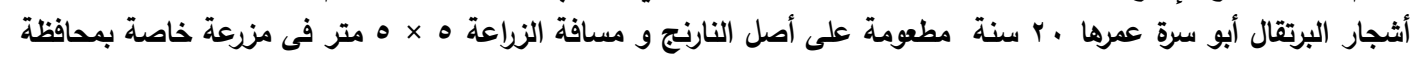

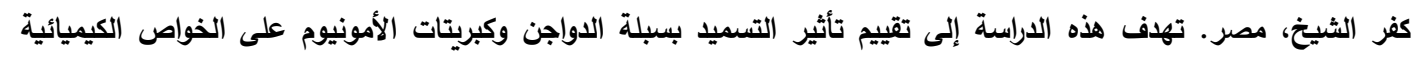

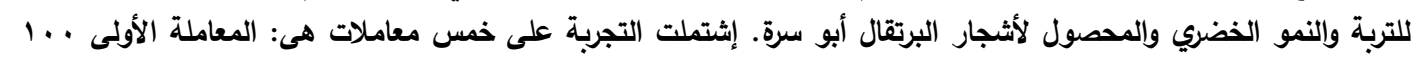

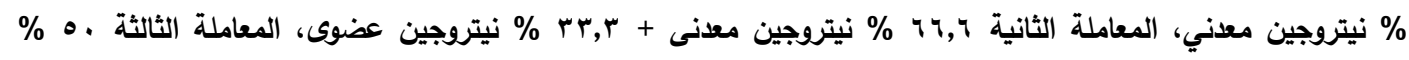

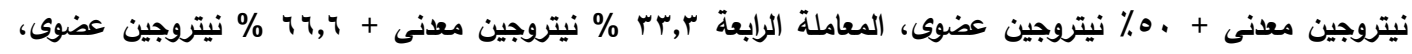

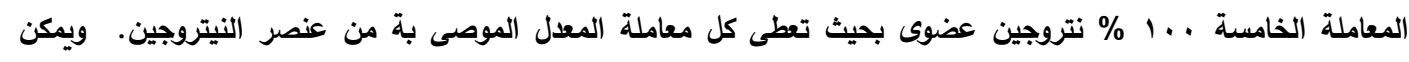
تلخيص أهم النتائج فى النقاط التالية:

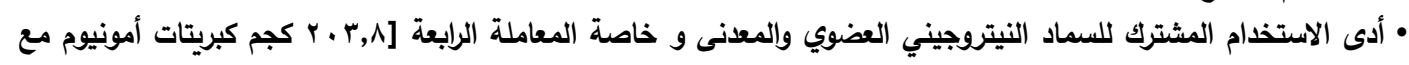

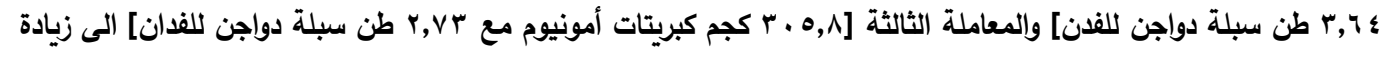

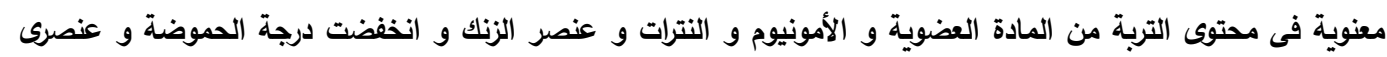

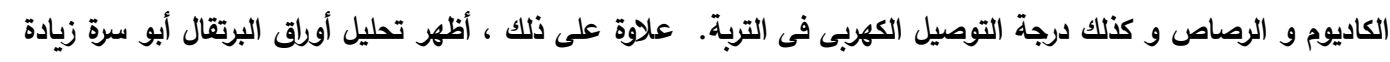

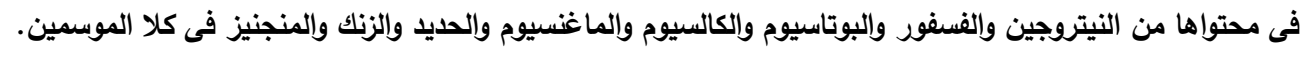

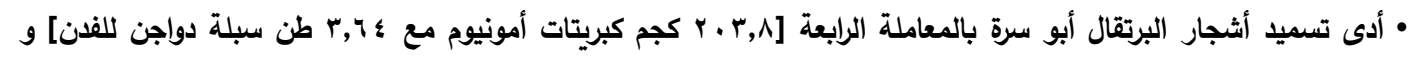

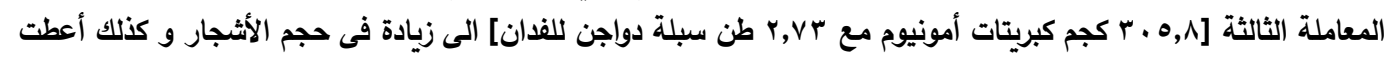

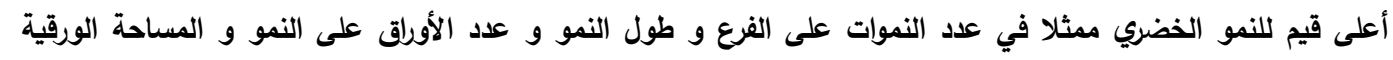

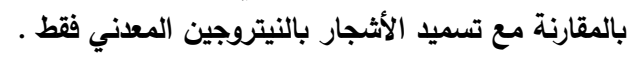

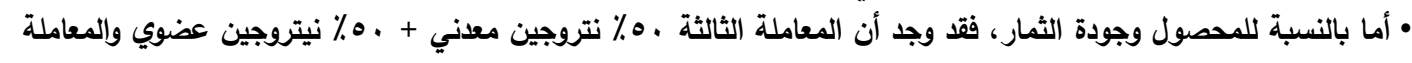

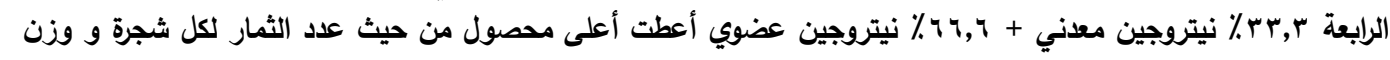

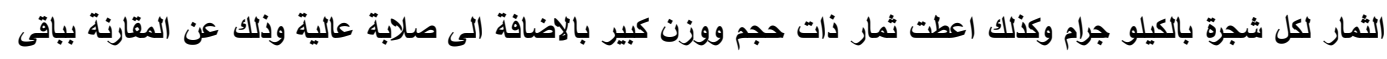

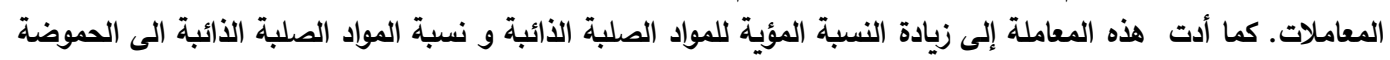

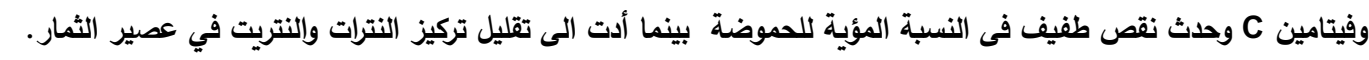

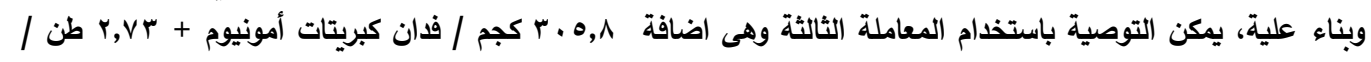

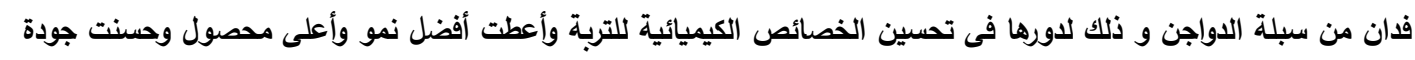

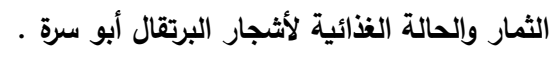

أسماء السادة المحكمين

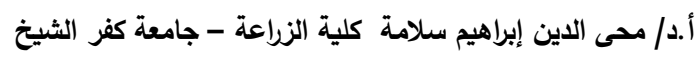

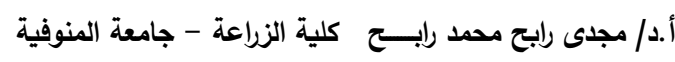

